\title{
Behavioral observation in America: The Spanish pioneers in the 16th and 17th Centuries
}

\author{
JAVIER BANDRES, J. JAVIER CAMPOS, and RAFAEL LLAVONA \\ Universidad Complutense, Madrid, Spain
}

(Anthony A. Wright, Sponsor)

\begin{abstract}
Behavioral observation by Europeans in America began shortly after the arrival of the Spaniards. The discovery of animals completely unknown in the Old World was followed by a strong interest in the description of the new species and their behavior. Fernández de Oviedo, Sahagún, Hernández, Acosta, and Cobo were among the more important Spanish naturalists who described the behavior of American animals during the 16th and early 17th centuries.
\end{abstract}

A recent article on Thomas Morton (1624-1646) (Gray, 1987) claims that he was the first behavioral observer in America. But, here, as with so many issues of historical precedence, one can discover roots even further back in time. In order to avoid this trap ourselves, in this paper we will discuss some systematic behavioral observations made in the New World, which predate Morton by 100 years. Our only claim is that this was probably the first such effort by Europeans in America. Behavioral observation started in the New World with the arrival of the first Spanish explorers and scientists at the beginning of the 16th century. The work of these pioneers is not an isolated chapter, but a part of an enormous effort instigated and supported by the Spanish Crown and the Church. Its purpose was to illuminate the new problems that the discovery of America had introduced for the intellectual minds of the Renaissance. For example, the descriptions of species unknown in the Old World made the Spanish naturalists take up the question of the origin of species and forced them to reconcile such new facts with the version derived from Biblical texts (Acosta, 1590/1954).

The conquest of America and the accompanying search for resources elicited intense intellectual activity. The first printing press was taken to New Spain in 1536, by Bishop Zumárraga. A few years later, books were printed not only in Spanish, but also in Nahuatl, the Aztec language. In 1551, the Spanish Crown founded the Universities of Mexico and Lima, where law, medicine, philosophy, and theology were taught (Barreiro, 1935). During the 1500's and 1600 's, more than 15 Spanish naturalists carried out observations of animal behavior in America. Here, we will concentrate on 5 of them.

\footnotetext{
We wish to thank Lucía del Moral-Haworth for her able assistance in translating the Spanish texts. We are deeply indebted to Anthony A. Wright and Robert A. Boakes for their helpful comments. Reprint requests should be sent to Javier Bandrés, Dpto. de Psicología Básica II, Facultad de Filosofia, Edificio A, Universidad Complutense, Ciudad Universitaria, 28003 Madrid, Spain.
}

\section{The Men and Their Work}

Gonzalo Fernández de Oviedo arrived in America in 1514 as an overseer of the gold smelting. As a gentleman who had visited the great courts of Europe, he was full of the spirit of investigation and natural observation. In 1526, he published Sumario de la natural historia de las Indias, which included descriptions of 52 American animals. His definitive work was published in 1535, the Historia general y natural de las Indias, islas y tierra firme del Mar Océano (Fernández de Oviedo, 1535/1959). These four books included an enlarged edition of the Sumario, together with descriptions of insects, birds, and aquatic and terrestrial animals. Its impact was such that in his lifetime 15 editions were issued; it was translated into five other languages (see López-Piñero, 1982, p. 27). The descriptions of animals included morphological and nutritional observations, as well as behavioral ones. The following are a few examples from the Sumario: About the anteater bear, Fernández writes,

It has this form so as to be able to reach the hidden ants causing their death; it goes to the mentioned anthill, and through a crevice or crack as thin as a sword's edge, it starts placing its tongue and dampens the crevice by licking it, even though it is very thin; and its saliva has such peculiar qualities and the animal's perseverance in licking is so continuous that little by little it manages to widen the crevice, allowing it at will to introduce and withdraw its tongue from the anthill. Its tongue is very long and thin and disproportionate to its body. When it has widened the crack enough, it introduces its tongue as far as it will go through the hole it has made, staying still for a long time. As there are large quantities of ants and they are attracted by dampness, a large amount of them crawl onto the tongue in such quantities that they can be grabbed in fistfuls. When the anteater bear thinks that it has enough, it withdraws its tongue into its mouth and eats the ants clinging to it. When it has eaten them it goes back for more. (p. 102)

About the sloth, ironically named by Spaniards the "light parakeet," he writes, 
The light parakeet is one of the clumsiest animals that can be seen in the world, and so heavy and awkward in its movements that to walk fifty steps it needs a whole day.... Its voice is very different from that of all other animals, because it can only be heard during the night and it never stops singing. From time to time, it sings six notes, each one higher than the next, always descending, so that the highest note is the first and the rest from then on descend, the voice fading, as if someone were saying A, G, F, E, D, C; in this way this animal says ha, ha, ha, ha, ha, ha. (p. 106)

About the "cat-monkeys," he says,

They are so cunning that they imitate and carry out many things that men do. There are many that, upon seeing how an almond or pine nut is opened with a stone, will do the same thing in the same way. They will open all that is given to them, provided that a stone is placed where the 'cat' can reach it. They can also throw a small stone of the size and weight that their strength is capable of, as a man would do (p. 109)

Our second behavioral observer, Friar Bernardino de Sahagún (1500-1590), was a Franciscan monk who reached America in 1529 after having studied in Salamanca. In 1540, he started to collect data for his Historia general de las cosas de Nueva España, a work commissioned by the provincial Francisco Toral and completed between 1550 and 1569. Unfortunately, it was not published during his lifetime, and for a long time it was available only as a manuscript (see Sahagún, 1969). This work includes studies of medicine, astrology, botany, zoology, and mineralogy. Sahagún compiled vast quantities of data on American nature by interviewing the Indians, to whom he had privileged access because of his knowledge of the Nahuatl language. To reduce the fantasy often involved in free descriptions of animals, Sahagún used a questionnaire that had to be followed by his informers. As reconstructed by Garibay from the records of the Indians' responses (see Sahagún, 1969, Vol. 3, pp. 216-217), it contained the following: (1) The name of the animal; if it has more than one name, then give them all. Also, give reasons for the animal names. (2) What is the animal like? What are its distinguishing characteristics? (3) Where does it breed and live? (4) What does the animal do? What is its job if it has one, whether good or bad? (5) How does it obtain its food, and what methods does the animal use if they are unusual? (6) How can they be caught or hunted? (7) Habits and particularities worth mentioning. (8) Folklore and stories in which the animal is mentioned. (9) Sayings derived from its customs.

Here are some examples from the observations concerning more than 250 animals collected by Sahagún:

On the squirrels:

They eat everything they find-bread, meat, and fruit; they eat whatever there is to be eaten, and even if you try to take their food away from them, they are not afraid and don't leave the food; they steal imperceptibly and that's why they eat what is hidden away. Some squirrels breed in the mountains and in the trees; these eat pinenuts and the tender treebuds, and caterpillars that breed in the trees; they peel the bark of the trees so as to reach the caterpillars from the inside. (Vol. 3, pp. 228)

On the turtle doves, called "cocotli":

They are called cocotli because when they sing they say coco coco.... They mate for life, and when one dies the other goes around by itself as if it were crying, saying coco coco. (Vol. 3, pp. 254-255)

On the quails:

They live in groups in the country; when scattered, they call to each other so as to be able to get together again.... When someone comes upon the quail chicks that have not yet learned to fly, their mother, who is always with them, starts to flutter near the intruder, pretending she cannot fly away, in order to distract his attention from the chicks so that they have time to hide; when she sees that they are safe, she takes off and flies around; later on, the chicks will run back to her after hearing her whistle; it is said that this custom is also followed by the partridges in Spain. (Vol. 3, p. 255)

During the first years following the discovery of the new lands, the conquerors sent back to Spain tales that aroused confusion and distrust because their objective descriptions of nature were shrouded in fantasy. In 1570, the first modern scientific expedition reached New Spain with the support of King Philip II; its aim was to discover which stories were true and which were false. At the head of the expedition, as scientific director, was Dr. Francisco Hernández (1514-1578), the Palace Physician and Physician to the Guadalupe monastery. He was named first Physician Inspector of the New World (see Steele, 1982, p. 13). His Historia natural de Nueva España, written between 1570 and 1577 , contained 6 volumes of text and 10 volumes of drawings. In them he described, among other things, plants, animals, minerals, and the ethnography of the New World. The greater part of this immense work was not published in his lifetime, even though King Philip II ordered Dr. Reccho to take charge of the publication of the medical data. Hernández described in the Historia natural de Nueva España more than 300 different animals, grouped as quadrupeds, birds, reptiles, insects, and aquatic animals. His texts were illustrated with drawings made by artists included in the expedition for this purpose. Hernández died soon after returning to Spain, in 1578. A great part of the original manuscript disappeared in the fire of the Escorial Monastery Library in 1671. A few editions were compiled from copies that were still to be found in various locations, which made Hernández well known in Europe (see Hagen, 1944; Humboldt, 1830). He gave morphological and behavioral data on animals, with an emphasis on their medicinal properties.

Hernández's descriptions are occasionally rather mentalistic, not unlike those of Romanes (see Boakes, 1984, 
p. 37). Thus he writes of the Tlacuatzin, a Mexican marsupial (Didelphis virginiana),

It climbs trees with incredible agility; it hides for long periods of time in caves, it kills and eats hens just as foxes and weasels do, decapitating them so as to drink their blood. Apart from this it is harmless and without malice even though with instinctive cunning it pretends to be dead sometimes, when there is no other way of escape from man, or to deceive its enemies and bite them. (Hernández, 1959, pp. 298-299)

Of the Coyotl, or Indian fox (Canis Latrans cage), he writes,

[It is] a clever hunter with habits similar to those of the fox, and such an obstinate avenger of any injury committed against it that, if a thief takes a prey from it, it won't forget. Later, when it recognizes the thief, it will ambush him with other members of its species, attacking, biting, and if possible, killing. After carefully observing the home of the thief, it will find a way of getting in and killing all the domestic animals it finds, avenging itself in this way for the injury done to it and punishing its enemy, man. On the other hand, it is grateful to those who help it, so if it is given a few hens to eat, it will not attack and kill the rest of the hens. (p. 302)

Of the Tptototl, or pheasant, he tells us,

It is tame and friendly with man; it asks for food by pulling at their clothes, and when it wants to go into a house, it calls on the closed door with its beak; if set loose it will follow its owner around; and when its owner comes home, it will welcome him enthusiastically. (pp. 340-341)

Of the Toznene, a yellow parrot, he says,

It is clever and better able than others of similar species at imitating human language, especially the Spanish language.... It chooses certain trees in which to live and does not leave them for others' trees. These animals move both jaws, something which no other animal does. (pp. 344-345)

Father José de Acosta (1539-1600), a Jesuit, arrived in America around 1573. He lived in Santo Domingo, Mexico, and Peru, and in 1587 he returned to Spain. Three years later, he published his Historia natural $y$ moral de las Indias (1590/1954), which was published in 32 editions in his lifetime and translated into six languages (see López-Piñero, 1982, p. 27); it also appeared in an English edition (Acosta, 1604).

Acosta's work comprises seven books: The first three are about American geophysics, the fourth is about minerals, plants, and animals; and the last three deal with history and ethnography. It is full of theoretical implications and hypotheses regarding the fauna and flora of the New World. It contains reference to more than 30 different animal species. Here are two examples:

On the Indian monkeys:

Twisting their tails around a branch, they are able to move anywhere they want, and when the distance is so great that they cannot use this method of moving around, they use a strange way of holding each others' tails, making a chain. The one that is at the top, helped by the strength of the rest, swings and jumps and grabs a branch supporting the rest until they all get to the branch. Teasing, lies, and pranks in this species are a difficult business to be described here. When taught, they learn so many things that they don't seem like beasts, but animals with human judgment. ... I don't think that there is an animal that perceives in such a way and that adapts itself to human conversation as this type of monkey. (p. 134)

\section{On the alpaca (Agouti paca L.):}

The alpacas sometimes get moody and bored because of the load they carry; they lie down and there is no way of making them get up again; they will let you cut them to pieces before they will get up again when they are in that mood.... The remedy of the Indians is to stop and sit down by the alpaca and caress and fondle it until it gets over its mood and stands up again, and sometimes they spend hours until they calm down. (p. 137)

Bernabé Cobo (1580-1657), inspired by his spirit of adventure, arrived in America in 1596. He joined the Society of Jesus in 1601 . He traveled through different parts of Peru, and in 1629 he went to New Spain, where he traveled for 13 years. He then returned to Peru, where he finished editing his Historia natural del Nuevo Mundo, a work divided into three parts and 43 books. The first part, about natural history, comprises 14 ; almost all the rest of the books have been lost. The work remained unpublished until the beginning of the 19th century, when a few fragments finally came out (Cabanilles, 1804). In 1891, the books on natural history were published (Cobo, 1891). The seventh book is about fishes, the eighth about birds, and the ninth about insects, reptiles, and other terrestrial mammals. These three books describe more than 250 American fauna. The animals introduced into America by the Spaniards are described in the tenth book. Of all the pioneer observers, Cobo was perhaps the most perspicacious in his descriptions of animal behavior and his inferences regarding mental processes.

Here are a few examples: Of a little bird called "zarcillo," he writes, "They fly so high and make such a noise that they annoy people; the noises they make are similar to the noise made by children crying. They usually fly in two rows set in triangular form. Where the two rows finish there is one that guides the rest"' (p. 205); of the "chief magistrate," "This bird is the sentry and watchman of the rest, because when a bird of prey appears, it warns the others, which have time to escape to a safe place"' (p. 216); of the glowworm, "Wherever they fly, they illuminate the night as if they were candles.... The way they are caught on this island is as follows: they fly around in the air from the moment night falls, resembling firebrands or lighted candle wicks; whoever wants to catch them has to hold a light and move it about in a way similar to the way in which they fly; they will fly to the light, thinking that it is one of their own kind, as far as we can tell" (pp. 259-260); of the monkeys, "The Indians call 
the biggest of them all 'sacharunas,' which means 'wild and sylvan men.' The Indians believe them to have particular instincts ... and the only reason they don't speak is that they do not wish to pay taxes or serve anyone; and it seems that if they could speak, they would be completely rational beings" (p. 312).

Finally, here is Cobo's description of a simple experiment with fishes, concerning the spatial orientation of the so-called "Peje-bobo":

There are three kinds of this species in the Alvarado river; each one of them comes from a different river...each one of them spawns at the opening of the Alvarado River in a different place. The young of each species return up the river to the place where they and their parents came from; and they keep strictly to different paths when they return to their native homes and never mingle with the others; you can see three different lines of fishes in the water.... It has happened that some people, out of curiosity, collected a bowl of fishes from one shoal and dropped them on to the opposite shoal and, even though they were so small, they returned with their relatives to their place and homeland. (pp. 165-166)

\section{The Natives, the Europeans, and Animal Life}

Any discussion about who was the first behavioral observer in America must necessarily refer to the native Americans; this honor belongs to them. Dr. Francisco Hernández describes in his work Antiquitatibus Novae Hispaniae the huge zoological installations that the Aztec chief Montezuma had in his palace. Hernández states that this zoo contained marine and freshwater birds, as well as lions, tigers, panthers, bears, and wolves. And there were also snakes, lizards, and crocodiles. The zoo employed 300 men, whose work consisted of breeding and training birds of prey (Hernández, 1946, pp. 96-97). Francis Galton knew of the existence of these bird keepers of Montezuma in México and of the zoos of the city of Cuzco in Peru, through the writings of López de Gomara, a lieutenant in the army of Hernán Cortés, and through the writings of Inca Garcilaso de la Vega (Galton, 1883, pp. 257-258).

Thus, it seems that the original behavioral observers, whether Europeans or American natives, were located in the viceroyalties of Perú and New Spain, which included the Mexico and part of the southern United States of today.

\section{REFERENCES}

AcosTA, J. DE (1604). Natural and moral historie of the East and West Indies. London.

AcosTA, J. DE (1954). Historia natural y moral de las Indias. In F. Mateo (Ed.), Obras del Padre José de Acosta. Madrid: Atlas. (Original work published 1590)

Barreiro, A. J. (1935). La "Historia del Nuevo Mundo", del P. Bernabé Cobo, S.J. In Asociación Nacional de Historiadores de la Ciencia Española (Eds.), Estudios sobre la ciencia española del siglo XVII (pp. 225-263). Madrid: Gráfica Universal.

Bonkes, R. (1984). From Darwin to behaviourism. Cambridge, England: Cambridge University Press.

CAbanilles, A. J. DE (1804). Discurso sobre algunos botánicos del siglo XVI. Anales de Ciencias Naturales, VII.

Сово, В. (1891). Historia del Nuevo Mundo. Seville: Imprenta E. Rasco.

FERNÁNDEZ DE Oviedo, G. (1942). Sumario de historia natural de las Indias (E. Alvarez, Ed.). Madrid: Summa. (Original work published 1526)

FERNÁNDEZ DE OviEDo, G. (1959). Historia general y natural de las Indias (J. Pérez de Tudela, Ed.). Madrid: Atlas. (Original work published 1535)

GALTON, F. (1883). Inquiries into human faculty and its development. London: MacMillan.

Gray, P. H. (1987). Thomas Morton as America's first behavioral observer (in New England 1624-1646). Bulletin of the Psychonomic Society, 25, 69-72.

HageN, V. (1944). Hernandez' travels in the New World. The Scientific Monthly, 58, 383-385.

Hernández, F. (1946). Antigüedades de la Nueva España. Mexico: Pedro Robredo.

Hernández, F. (1959). Obras completas: Tomo 3, Vol. 2. Historia natural de Nueva España. Mexico, D.F: Universidad Nacional de México.

HumboldT, W. (1830). Erklärung einiger Tiernamen aus Hernandez Thesaurus rerum medicarum Novae Hispaniae. Abhandlungen der Königlichen Akademie der Wissenschaften zu Berlin. 124-127.

Lopez-Piñero, J. M. (1982). La ciencia en la historia Hispánica. Madrid: Salvat.

SAHAGÚN, B. DE (1969). Historia general de las cosas de Nueva España (2nd ed.; A. M. Garibay, Ed.). Mexico, D.F: Porrúa.

Steele, A. R. (1982). Flores para el Rey. Barcelona: Ed. del Serbal. (Original English edition published 1964)

(Manuscript received May 28, 1988.) 